\title{
The Training Reform of Students' Practical Ability in Social Sports Majors of Agricultural and Forestry Universities under the Background of Innovation and Entrepreneurship
}

\author{
HuHu Lian, XiaoWei Di \\ Sichuan Agricultural University, Ya'an, Sichuan, China
}

Keywords: Agricultural and forestry universities; Practical ability; Innovation and Entrepreneurship; PE majors.

\begin{abstract}
In the context of innovation and entrepreneurship, it is necessary and urgent to reform the training patterns according to the national policy orientation and the development of universities, colleges, majors and students themselves. Especially for the PE majors in agriculture and forestry universities, it is of great importance to seek the innovation. Therefore, Sichuan Agricultural University proposed the reform plans and analyzed its feasibility: To reposition the major and find out the characteristics; Innovation on campus practical platform; To reasonably increase practice credits and academic period; To reform teaching methods and evaluation methods; To strengthen the integration of schools and enterprises and build bases for agriculture; To guide students to participate actively in scientific research practice. Under the reform, the following results have been achieved: The establishment of the platform has greatly enhanced the students' sense of belonging in majors; The increase of practice credits has greatly stimulated students' interest in learning; The various teaching methods has truly realized "Teachers are guides, students are subjects"; The more practice bases has broadened the student's employment; The improvement of students' scientific research ability has strengthened students' social adaptability.
\end{abstract}

\section{Introduction}

Guidance of National Policies. Issued in March 2015, the Opinions on the Implementation of Deepening Innovation and Entrepreneurship Education Reform in Higher Schools by the General Office of the State Council pointed out that one of the reform tasks is to "perfect innovation and entrepreneurship education curriculum system. According to the positioning of talent fostering and the goal requirements of innovation entrepreneurship education, schools should promote the integration of major education and innovation entrepreneurship education, adjust the major curriculum, look for and enrich all kinds of innovation and entrepreneurship education resources of major courses, strengthen the innovation and entrepreneurship education in the process of imparting professional knowledge."

In recent years, the State Council, the Ministry of Education and the State Administration of Sport have issued a series of policies and documents. It states that the sports development of our country will be further inclined to the national fitness. In particular, in 2016, a number of important documents have been issued. The promulgation of these documents marks that the policy guidance mainly focuses on the great space of the sports industry and the domestic demand boosting, consumption promotion and employment increase by the development of the sports industry.

As a bridge with the society, universities bears great responsibilities and obligations. In order to adapt to the rapid development of the sports industry, college sports should be repositioned. In particular, the cultivation of students' practical ability can play a crucial role in the students' ability to adapt to society. 
The Development Need of Schools, Colleges, Majors and Students. With the development of sport education in regular higher schools and the expanded enrollment scale, different types of sports majors in higher schools have been running for nearly a decade. Although it has accumulated some experience which has promoted the discipline development of the school, if it is similar to that of sports colleges, it will not only cause the waste of resources, but also will gradually lose the space and conditions of development.

Sichuan Agricultural university is the national "Project 211" key construction university. The sports college of the university was established in 2016 and developed gradually from the sport teaching and researching group of Sichuan Agriculture College in 1956. The teaching experience of more than 10 years in sports major has promoted the major development of the school. However, although trying to get rid of the sports colleges' running mode, and finding its own characteristics, the effect is not ideal. Therefore, considering the development need of schools, colleges, majors and students, and the sports major of Sichuan Agricultural University must be reformed. Otherwise, it will result in the repeating running, the limited development of the college, the lack of professional competence and the weak competitiveness of students.

\section{The Feasibility Analysis of the Reform}

With its multidisciplinary complementation, Sichuan Agricultural University has a unique advantage in the development of sports majors involving in the field of agriculture. The school has independent recruitment. In recent years there have been adjustments in the revision of major training programs. Especially in specific problems such as major credit structure, curriculum setting and academic period allocation. Relying on the excellent educational conditions and resource advantages of "Project 211", and starting from the aspects of "cultivating goal - theory teaching - skill learning practical application" in the talent training plans of sports majors, the sports college has gradually formed its "agricultural" characteristics that serves the development of urban and rural integration. Therefore, it is not only necessary to reform the practice ability of sports students, but also has a certain effect.

\section{The Reform Plans}

Identify the Position and Find Out the Characteristics. Through the objective analysis of the positioning and the advantages of the social sports major in sports college, The university constructed the agriculture-involved training mode in the combination of "theory - practical training and skills". It broke through the mode of "focus on technology, despise theory and practice" in traditional sports colleges. The theory study is the foundation, mastering the skill is the purpose, the practical link is the key. The result mainly focused on the reform and innovation of traditional theory course teaching: The sports courses involving agriculture was added, the agriculture-involved teaching material was published; Creating a major atmosphere of "strong technology and focus on skills", building special major skills competition for "one major, various abilities", and encouraging students to examine and obtain professional certificates of various countries; Based on social practice, supported by the practice in the university, and featured by the agriculture-involved practice base, realizing the close combination with the employment and entrepreneurship under the new situation. The aim is to cultivate the sports application talents who adapt to the development of society.

Innovation on Campus Practical Platform. At the beginning of 2017, the sports college established the "Fitness Service and Guidance Center for College Students". The center aims to coordinate with the school sports committee and youth league committee to build a platform for students to fully develop and train their students' practical ability. With the rapid development of society, students can hold competitions within the campus by learning and applying the planning, publicity, organization, management. The college can also cultivate talents that are useful to the college, the school and the society. In this way, the effect of "co-operating, mutual gains, and win-win" can be achieved. The operation of the center is guided by the professional guidance teachers of the tournament while the main work is done by the students themselves. They are mainly 
responsible for planning, publicity, organizing, management and service, so that students can participate in the practice and apply the knowledge learned in the classroom to the practice. The center is founded for strengthening students' professional skills and broadening the way of application of students' practical ability. The center encourages students to participate in relevant sports events at all levels. They not only need to improve skills in the events, but also learn to plan, organize and even manage the events. And the cultivation and practice level of these abilities is one of the important abilities needed at work.

Reasonable Increase in Practice credits and Academic period. Compared with the related content of the undergraduate talent training plans of Sichuan Agricultural University in the last three years, The training plan developed by the school embody the importance of practical courses from the major introduction, graduation credit requirements, classroom teaching arrangement, practical teaching arrangement and elective courses. On the one hand, it increases the credit of practical teaching courses and increases the academic period of the course practice. Take sports technology special course as an example. It took 7 credits for students of 2015, while the total academic period is 112, and 56 in both fifth and sixth terms. For the students of 2016, the total number of credits have been adjusted to 8 credits, while the total academic period has been increased to 128 . The fifth and sixth terms were arranged for 64 respectively. The increase of the credits and the academic period reflected the trend of the increasing practical opportunities of the sports majors in Sichuan Agricultural University, which is conducive to strengthening students' technical specialty. Take the 2015 social sports guidance and management major as an example. The total credits are 165 . The credits of courses in practical teaching is 21 , which is $12.8 \%$ of the total. The total number of practice weeks is 44 weeks. On the other hand, through skill display and skill competition, the atmosphere of "strong technology and focus on skills" is built to make students understand that "hard work should paid after class". The school encourages students to pass special courses, such as bodybuilding, fitness and swimming, to get vocational skills certificates that are accepted by many countries and lay a good foundation for employment and entrepreneurship.

Reform Teaching Methods and Evaluation Methods, Strengthen Teaching Practice Link, Basically Form "Experts Bring In, Students Go Out". The college pays attention to the combination of theory and practice. The core curriculum has been added the academic period of teaching practice, which means that the teachers need to led the students to the internship company and the related enterprises and institutions to visit and study. Most of the lessons are taught in class and after class in order to strengthen students' understanding and application of theoretical knowledge in practice.

In class, through the reform of teaching methods and evaluation methods, the college strengthened the examination of the practice link. The college tried to combine theory with practice in teaching method and tried the "flipped classroom" teaching method. Teachers became the guidance and students became the subjects. The class changed from teaching to communication. The links such as "hot topic discussion", "presentation", "social investigation", "mutual assessment", "case analysis" were added in class, which greatly increased the participation of students. Teachers guided students to see the problems in a multi-angle and multi-level view. In the process of discussion, evaluation and analysis, the students were encouraged to study with critical thought to overcome their boring and difficult impression toward the theory course. It also promoted the communication and interaction between teachers and students. Speaking of the evaluation methods, the examination in ordinary time was strengthened. the quality of the homework and the schedule of the lesson were put into the assessment of ordinary performance. And the college implemented the "all-pass" assessment standard, and increased the periodical assessment.

After class, on one hand, the college has invited well-known experts in the related industry to guide the students from various perspectives and in-depth level. On the other hand, Relevant documents have been implemented and students' practical ability has been strengthened. The revised Undergraduate Teaching Management Measures in 2016 pointed out clearly: Undergraduate students should obtain credit for innovation and entrepreneurship (2 credits). Students can obtain credits for 
innovation and entrepreneurship through social practice, public publication, academic conference paper exchange, skill certification, "five plans" and various kinds of competition certificates.

Strengthen the Combination of the School and Enterprises, Build Agriculture-involved Bases, Expand teaching practice and Employment Practice Bases, and Form a Good Atmosphere of " Do Practice on Vacation, Do Support Education in Ordinary Time". In recent years, the college has signed teaching practice bases with more than 20 employers. Every year, the college organizes students to work in the signed company which makes the study closely connected with employment and entrepreneurship. The school has established a relationship with the high-end gym clubs in Chengdu. At the same time, it has established agriculture-involved practice bases with the sports bureau of Mingshan county, Yongan town in Shuangliu and Lushan county. Every year, the college organizes students of Sports Education major to Hongcao middle school in Mingshan, Caoba middle school in Ya 'an, Duiyan middle school, Zhongli middle school and other rural schools to conduct teaching practice. The college also organizes students to Maohe town in Mingshan, Yongan town in Shuangliu, the nearby villages in Lushan county to promote the national fitness project in order to cultivate students' sense of responsibility and service awareness in rural sports.

Guide Students to Actively Participate in Scientific Research Projects while Strengthening Professional Skills, to Form "Research for Practice, Matches for Study, Matches for Exercise". According to the related policies and documents, the students should participate matches in different levels to improve their professional skills. The teachers should guide the students to do practice activities after class. They should pay more attention to the cultivation of students' research awareness and encourage them to do scientific research. The college has set up innovative training programs, research interest training programs, and professional skills improvement programs to encourage students to participate in scientific research. The college encourages students to take postgraduate entrance exams and guide them in daily management. In preparation for their postgraduate entrance exams, the college combines the teachers with the students' scientific research, encourages teachers to guide students to keep in touch with research teams, which can fully improve the students' scientific research ability and scientific research level.

\section{Performance}

The College Students' Fitness Service and Guidance Center has organized nearly 10 university-level competitions and trainings in less than half a year since its establishment. The number of participants involved nearly half of the students in the sports college. This platform let the students have the feeling of working. It gives the students chances in applying their knowledge to practice. It also gives students the opportunity of making mistakes and correct them in practice. The more important is that it provides opportunity for students to learn from practice which will help them a lot in the future. According to the center's director, the center will organize a series of sports activities with the school sports committee, the youth league committee and the student union such as sports culture festivals, professional skills competitions, and college sports activities. Gradually the center will expand the service object to the whole university and even the society, to provide more space for students' practice exercise.

The increase of practice credits and academic period has greatly stimulated the students' interest in learning.

The various teaching methods indicates that teachers have become the guidance and students have become the subjects. The class has changed from teaching to communication which has increased their participation degree and has guided students to see the problems in a multi-angle and multi-level view. In the process of discussion, evaluation and analysis, the students are encouraged to study with critical thought to overcome their boring and difficult impression toward the theory course. It also promotes the communication and interaction between teachers and students. In the reform of the assessment, the mode of simple memorization of knowledge has been broken, the intensity of curriculum training has been increased, classroom teaching, classroom management and curriculum supervision have been paid more attention, and students' practical ability and applying ability have 
been developed. Most students, under the guidance of the policy, take the initiative to use the winter and summer vacation, various holidays, and other extracurricular time to do social practice.

The establishment of the practice bases provides internship and training for students in sports majors which cultivates and exercises students in the actual use of learning, and enhances students' practical ability. At present, the coaches in the gyms, and swimming pools of Ya'an are basically students in our college. The graduate students of our college and our university all have good social response, which reflects their excellent quality such as hard-working, hands-on ability, strong team spirit, strong coordination.

In recent years, sports students in scientific research and professional skills breakthroughs continued to make achievements. On this basis, the number of college students who have successfully admitted to the international elite schools increased. The number of graduate students of "985", "211" increased year by year. More and more students get the opportunity to study further. A large number of students became PE teachers in rural areas. Some of them became the selected graduates, village officers and a member of "West Plan", etc. Some of them went to the agriculture-involved companies such as the Hope Group, Tie Qi Group, etc. The school actively organized students to participate in provincial, state-level skills competitions and lectures. This shows the strength of the university and the width and social adaptability of the talent training quality.

\section{Conclusion}

Through various approaches, Sichuan Agricultural University has made great achievements in the reform of the practice ability of sports students. However, the plan still need to be adjusted gradually with the development of the times. The university should "jump out of sports to see it", and combine its own major characteristics and educational philosophy to cultivate students' all-round development.

\section{Acknowledgements}

Fund Resource: The staged achievements of the school - level teaching reform project of Sichuan Agricultural University Reconstruction and Perfection of Curriculum System of Social Sports Major under the Background of Innovation and Entrepreneurship, Project Number: X2015046. Fund Resource: The staged achievements of the Social Science Union special project of Sichuan Agricultural University Research on the Reform of Practical Ability Training for PE Majors in Agricultural and Forestry Universities, Project Number: 2017YB10.

\section{References}

[1] General Office of the State Council. Opinions on Strengthening School Physical Education to Promote Students' Overall Development of Physical and Mental Health [Z].2016-05-06.

[2] General Administration of Sports of China. The "13th Five-Year" Sports Development Planning [Z].2016-05-05.

[3] The State Council. National Fitness Program (2016 - 2020) [Z].2016-06-15.

[4] The CPC Central Committee and the State Council. "Healthy China 2030" Plan [Z].2016-10-25.

[5] General Office of the State Council. Guidance on Speeding Up the Development of Fitness and Leisure Industry [Z].2016-10-25. 